\title{
Measurements of in situ stress and mining-induced stress in Beiminghe Iron Mine of China
}

\author{
OUYANG Zhen-hua(欧阳振华) ${ }^{1}$, LI Chang-hong(李长洪) ${ }^{2}$, XU Wan-cai(徐万才) $)^{3}$, LI Hao-jie(李昊洁) ${ }^{4}$ \\ (1. Institute of Mechanics, Chinese Academy of Sciences, Beijing 100190, China; \\ 2. School of Civil and Environmental Engineering, University of Science and Technology Beijing, \\ Beijing 100083, China; \\ 3. China State Construction International Corporation, Beijing 100026, China; \\ 4. Changjing River Scientific Research Institute, Wuhan 430010, China)
}

\begin{abstract}
In order to obtain the distribution rules of in situ stress and mining-induced stress of Beiminghe Iron Mine, the stress relief method by overcoring was used to measure the in situ stress, and the MC type bore-hole stress gauge was adopted to measure the mining-induced stress. In the in situ stress measuring, the technique of improved hollow inclusion cells was adopted, which can realize complete temperature compensation. Based on the measuring results, the distribution model of in situ stress was established and analyzed. The in situ stress measuring result shows that the maximum horizontal stress is $1.75-2.45$ times of vertical stress and almost 1.83 times of the minimum horizontal stress in this mineral field. And the mining-induced stress measuring result shows that, according to the magnitude of front abutment pressure the stress region can be separated into stress-relaxed area, stressconcentrated area and initial stress area. At the $-50 \mathrm{~m}$ mining level of this mine, the range of stress-relaxed area is $0-3 \mathrm{~m}$ before mining face; the range of stress-concentrated area is $3-55 \mathrm{~m}$ before mining face, and the maximum mining-induced stress is 16.5-17.5 MPa, which is $15-20 \mathrm{~m}$ from the mining face. The coefficient of stress concentration is 1.85 .
\end{abstract}

Key words: in situ stress; mining-induced stress; Beiminghe Iron Mine; stress measurment

\section{Introduction}

In situ stress is the primary acting force that leads to deformation and failure of geotechnical engineering such as underground mining, tunnel of transportation, and water conservancy and electric power engineering. Most engineers are inclined to know the in situ stress before their design. There are many kinds of measurement method for studying the recent tectonic stress field and stress state. Some typical and common methods include hydrofacturing [1-3], overcoring techniques [3-5], and acoustic emission [6-8]. In the underground engineering, when soil or rock mass is excavated, the balance of initial stress around empty area will be destroyed, and then, the stress redistributed. If the induced stress exceeds the ultimate strength, the surrounding soil or rock mass will be destroyed and move towards the empty area until the stress reached a new balance. The stress after redistributing was called mining-induced stress.

Beiminghe Iron Mine is affiliated with the Hanxing Metallurgical Mine Administration, China Minmetals Corporation, which is situated in the Shangtuan Village
Wu'an Country of Hebei Province, China. The geographic coordinate is $114.13^{\circ}$ in east longitude and $36.75^{\circ}$ in north latitude. And this mine is situated at an elevation of $280 \mathrm{~m}$. After two years mining, two ground collapse-pits and many collapse-fissures appeared on the ground surface around the measure-well, which made the well discarded. The bigger one of the two ground collapse-pits is about $20 \mathrm{~m}$ in length from east to west, and about $15 \mathrm{~m}$ in width from south to north. And the biggest collapse-fissure is about $400 \mathrm{~mm}$ in width [9]. In order to protect the mine production security and the surface ecological environment, some treatment actions must be taken to arrest the development of ground subsidence. In the recent years, more and more analysis and predicting methods [10-11] have been widely applied to the control of mining-induced surface subsidence. Whatever the method adopted, the knowledge of in situ stress and mining-induced stress are indispensable.

\section{Measurement of in situ stress}

\subsection{Measuring method}

In Beiminghe Iron Mine, the stress relief by

\footnotetext{
Foundation item: Projects(10702072, 10632100) supported by the National Nature Science Foundation of China 
overcoring technique was adopted to measure the in situ stress. For the improved hollow inclusion cell was adopted to measure the borehole strain that can realize complete temperature compensation [12-13], this method is of high accuracy and widely used [14-16] in the in situ stress measurement in China. Fig. 1 shows the structural general view of this kind of hollow inclusion cell, which contains three groups of strain gauges marked A, B, and C. And the three groups of strain gauges are arranged uniformly along the circumference by apart $120^{\circ}$. Every group strain gauge contains four strain cells, which have separately $0^{\circ}, 45^{\circ}, 90^{\circ}$ and $135^{\circ}$ separation angles with $Z$ axis. According to the measuring results of the 12 strain cells, the in situ stress can be figured out by the following formulas:
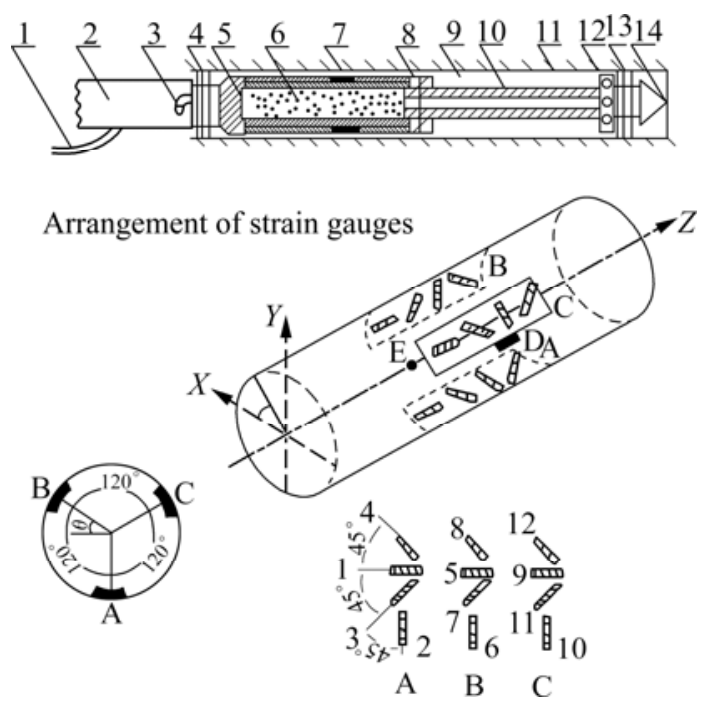

Fig.1 Structure of improved hollow inclusion cell: 1-Strain cell cable; 2-Erection lever; 3-Joint pin; 4-Back-end seal ring; 5-Ethoxyline resin; 6-Cavity; 7-Resistance strain gauge; 8-Fixed pin; 9-Interval between strain gauge and wall of borehole; 10-Plunger; 11-Bore-hole on rock mass; 12-Pore for glue outflow; 13-Front-end seal ring; 14Guide plug

$$
\begin{aligned}
\varepsilon_{\theta}= & \frac{1}{E}\left\{\left(\sigma_{x}+\sigma_{y}\right) K_{1}+2\left(1-v^{2}\right)\left[\left(\sigma_{y}-\sigma_{x}\right) \cos (2 \theta)-\right.\right. \\
& \left.\left.2 \tau_{x y} \sin (2 \theta)\right] K_{2}-v \sigma_{z} K_{4}\right\} \\
\varepsilon_{z}= & \frac{1}{E}\left[\sigma_{z}-v\left(\sigma_{x}+\sigma_{y}\right)\right] \\
\gamma_{\theta z}= & \frac{4}{E}(1+v)\left(\tau_{y z} \cos \theta-\tau_{z x} \sin \theta\right) K_{3} \\
\varepsilon_{ \pm 45^{\circ}}= & \frac{1}{2}\left(\varepsilon_{\theta}+\varepsilon_{z} \pm \gamma_{\theta z}\right)
\end{aligned}
$$

where $\varepsilon_{\theta}$ is the circumferential strain, $\varepsilon_{z}$ is the axial strain, $\lambda_{\theta z}$ is the shear strain, $\varepsilon_{ \pm 45^{\circ}}$ is the strain measured by the strain foil which has $\pm 45^{\circ}$ separation angle with the bore-hole axis, $\theta$ is the separation angle between the strain foil and $X$ axis, and $K_{1}, K_{2}, K_{3}$, and $K_{4}$ are coefficients, which can be found in Refs.[17-18].

\subsection{Selection of measuring points}

The veracity of in situ stress measuring results is influenced by many factors such as measuring methods, geological environment, and rock mass quality. For choosing the in situ stress measuring points, the following rules should be satisfied [19-20].

(1) The measuring points should be disposed in the initial stress area possibly, that is to say, in the area which is few disturbed by underground mining.

(2) The measuring points should be designed on continuous rock mass, where high cementation quality of hollow inclusion cell and bore is easily acquired, and intact stress relief measuring data and trepanning rock core can be obtained, which are very important to the subsequent laboratory test and results analysis.

(3) The in situ stress measuring points should be arranged far from the faultage because the horizontal stress is on the low level near these areas.

(4) Avoid aberrance, instability and interference of stress.

Considering the above rules, the mining design and obtained geological data, five representational in situ stress measuring points were selected in Beiminghe Iron Mine. Table 1 lists the situation and hole of the five points.

\subsection{Measurement results and analysis}

According to the stress relief curves of the five measuring points, the steady strain values of 12 strain gauges of every measuring point are listed in Table 2.

Through confining pressure calibration test, the elastic modulus and Poisson ratio of rock mass were measured. According to the strain, elastic modulus and Poisson ratio, the in situ stress values of every measuring point were obtained. In order to reduce error, F-test was adopted to reject abnormal data in the calculation. And the results are listed in Tables 3 and 4.

Form the in situ stress measuring results as shown in Table 4, the distribution rule of stress field in Beiminghe Iron Mine area can be summarized as follows.

(1) In the three principal stresses of every measuring point, two of them are nearly in horizontal direction, and most of the obliquities are less than $\pm 10^{\circ}$, the maximal one is $17.2^{\circ}$ in measuring point No.4. And there is also a principal stress nearly in vertical direction, and the vertical included angles are less than $18^{\circ}$.

(2) The maximal principal stresses of every measuring point are nearly in horizontal direction. Among the five measuring points, three horizontal included angles of maximal principal stress are less than $5^{\circ}$, the minimal one is only $0.6^{\circ}$, and the maximal one is 
Table 1 Situation and hole of every measuring point

\begin{tabular}{cccccc}
\hline Point No. & Point situation & Obliquity $/\left(^{\circ}\right)$ & Strike $/\left(^{\circ}\right)$ & Depth of hole $/ \mathrm{m}$ & Rock quality designation/\% \\
\hline 1 & -65 m level cross hole & 2.0 & 120 & 891 & 68 \\
2 & -110 m level shaft station & 2.5 & 314 & 941 & 73 \\
3 & East end of -230 m level flat lane & 2.0 & 21 & 933 & 80 \\
4 & -278 m level lane & 1.5 & 206 & 984 & 82 \\
5 & $-330 \mathrm{~m}$ level pulverous ore clearing lane & 3.0 & 195 & 956 & 79 \\
\hline
\end{tabular}

Table 2 Strain actually induced by stress relief

\begin{tabular}{ccccccccccccc}
\hline Point No. & $\mathrm{A}_{90^{\circ}}$ & $\mathrm{A}_{0^{\circ}}$ & $\mathrm{A}_{45^{\circ}}$ & $\mathrm{A}_{135^{\circ}}$ & $\mathrm{B}_{90^{\circ}}$ & $\mathrm{B}_{0^{\circ}}$ & $\mathrm{B}_{45^{\circ}}$ & $\mathrm{B}_{135^{\circ}}$ & $\mathrm{C}_{90^{\circ}}$ & $\mathrm{C}_{0^{\circ}}$ & $\mathrm{C}_{45^{\circ}}$ & $\mathrm{C}_{135^{\circ}}$ \\
\hline 1 & 348 & 256 & 116 & 104 & 172 & 272 & 120 & 296 & 278 & 300 & 220 & 132 \\
2 & 344 & 216 & 236 & 144 & 560 & 324 & 148 & 220 & 364 & 240 & 208 & 124 \\
3 & 324 & 216 & 148 & 180 & 560 & 500 & 132 & 552 & 328 & 120 & 252 & 164 \\
4 & 204 & 596 & 472 & 198 & 360 & 240 & 276 & 320 & 332 & 180 & 196 & 288 \\
5 & 560 & 248 & 396 & 368 & 416 & 432 & 380 & 456 & 480 & 360 & 252 & 408 \\
\hline
\end{tabular}

Table 3 Elastic modulus, Poisson ratio and coefficient

\begin{tabular}{cccccc}
\hline$E / \mathrm{GPa}$ & $v$ & $K_{1}$ & $K_{2}$ & $K_{3}$ & $K_{4}$ \\
\hline 67.8 & 0.33 & 1.074 & 1.116 & 1.048 & 0.982 \\
\hline
\end{tabular}

Table 4 Calculated results of in situ stress at different measuring points

\begin{tabular}{|c|c|c|c|c|c|c|c|c|c|}
\hline \multirow[b]{2}{*}{ Point No. } & \multicolumn{3}{|c|}{ Maximal principal stress measurement } & \multicolumn{3}{|c|}{ Medial principal stress measurement } & \multicolumn{3}{|c|}{ Minimal principal stress measurement } \\
\hline & $\begin{array}{c}\sigma_{1} / \\
\mathrm{MPa}\end{array}$ & $\begin{array}{l}\text { Direction/ } \\
\left(^{\circ}\right)\end{array}$ & $\begin{array}{c}\text { Obliquity/ } \\
\left(^{\circ}\right)\end{array}$ & $\begin{array}{c}\sigma_{2} / \\
\mathrm{MPa}\end{array}$ & $\begin{array}{l}\text { Direction/ } \\
\left(^{\circ}\right)\end{array}$ & $\begin{array}{c}\text { Obliquity/ } \\
\left(\left(^{\circ}\right)\right.\end{array}$ & $\begin{array}{c}\sigma_{3} / \\
\mathrm{MPa}\end{array}$ & $\begin{array}{c}\text { Direction } \\
\left({ }^{\circ}\right)\end{array}$ & $\begin{array}{c}\text { Obliquity/ } \\
\left({ }^{\circ}\right)\end{array}$ \\
\hline 1 & 21.99 & 92.3 & -0.6 & 10.55 & 174.1 & 85.5 & 9.14 & 2.3 & 4.5 \\
\hline 2 & 23.12 & 332.8 & -2.0 & 15.64 & 242.8 & -1.2 & 12.45 & 121.1 & -87.6 \\
\hline 3 & 24.72 & 295.9 & -5.9 & 15.07 & 205.5 & -4.0 & 13.23 & 261.8 & 82.9 \\
\hline 4 & 25.60 & 282.5 & -1.1 & 14.48 & 189.1 & -72.7 & 12.32 & 192.8 & 17.2 \\
\hline 5 & 31.60 & 117.9 & -10.4 & 20.64 & 209.0 & -6.2 & 17.92 & 329.2 & -77.9 \\
\hline
\end{tabular}

$10.4^{\circ}$. Comparing the maximal stress with gravity stress, the former is $1.75-2.45$ times of the latter. This result implies that the stress field of Beiminghe Iron Mine area is dominated by horizontal tectonic stress. The aptitude of the horizontal principal stress is in north-west, which is consistent with the maximal principal stress of regional tectonic stress field.

(3) Among the five minimal principal stresses, two of them are in horizontal direction, which shows that there is a great difference between the two horizontal stresses. The average ratio of the maximal principal stress to the minimal one is 1.83. According to Mohr-Coulomb strength theory, the shear stress is in direct proportion to the difference between the maximal and minimal principal stresses. This suggests that there is great shear stress in horizontal direction in Beiminghe Iron Mine. So, around underground mining area and lane, measures should be taken to avoid rock shear failure.
(4) The vertical stresses of this mine area are nearly equal to the gravitation of the overlying rock mass. In the five ratios of vertical stress to the self-weight stress of overlying rock mass, two of them are 0.998 , the other three are over 1.10, and the maximal is 1.23 .

(5) Accompanying with the alternative of depth, the stress is also changed. In order to find out the alternative rule, linear regression method is adopted to analyze the measuring results of the five points. Based on the analysis, the alternative rule, which is expressed by three equations of linear regression, is gained as follows:

$\sigma_{\mathrm{h}, \max }=1.934+0.0478 H$

$\sigma_{\mathrm{h}, \min }=0.409+0.0292 H$

$\sigma_{\mathrm{v}}=0.485+0.0272 H$

where $\sigma_{\mathrm{h}, \max }$ is the maximal horizontal stress, MPa; $\sigma_{\mathrm{h}, \min }$ is the minimal horizontal stress, $\mathrm{MPa} ; \sigma_{\mathrm{v}}$ is the 
vertical stress; and $H$ is the depth of measuring points, $\mathrm{m}$.

\section{Measurement of mining-induced stress}

\subsection{Measurement apparatus and principle}

MC type bore-hole pressure gauge, which is studied and developed by China Coal Research Institute, is a Chinese patent product with the characteristics of ideal sensitivity and veracity, and intuitionistic digital acknowledgement signal. So it has been applied widely to the measurement of underground engineering. Fig.2 shows the structure of MC type bore-hole stress gauge. It can be seen that this bore-hole pressure gauge mainly contains inclusion texture, pressure cushion, erection lever, oil pipe, pressure-frequency convertor, oil syringe, and testing cable.

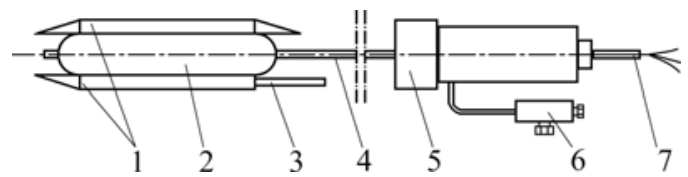

Fig.2 Structure of MC type bore-hole stress gauge: 1Inclusion textures; 2-Pressure cushion; 3-Erection lever; 4-Oil pipe; 5-Pressure-frequency convertor; 6-Oil syringe; 7-Testing cable

Combined with vibration theory of string wire and hydraulic pressure technology, MC type bore-hole stress gauge adopts liquid-expansion pressure cushion and self-contained complete frequency meter to measure the relative inner rock mass stress. Through the two inclusion textures, the changes of borehole rock stress can be delivered to the liquid-expansion pressure cushion and then changed into the liquid pressure. In succession, the liquid pressure will be delivered to the pressure-tofrequency convertor by the oil lead, and changed into frequency signal. According to the signal, the receiving apparatus can calculate and show the changes of stress.

\subsection{Choosing measuring points}

Because the measuring results obtained by MC type borehole stress gauge are relative variables, the measuring points should be set in the laneway around working face of mining. In this work, six measuring points of borehole pressure gauge were set in the 3-4, 6-2 and 6-4 laneway at the -50 mining level. According to the needed direction of measuring stress, the setting mode of MC type borehole pressure gauge can be chosen. That is to say, if you want to measure the horizontal stress, you can make the central line of the two inclusion textures in horizontal direction when you install the $\mathrm{MC}$ type borehole stress gauge. And if you want to measure the vertical stress, you can make the central line in vertical direction. In this measurement, all of the obtained results were vertical stress.

\subsection{Stress calculation}

According to the frequency of stress gauge in states of loading and without loading, the pressure of pressure cushion can be calculated by the following formula:

$p=C\left(f_{0}^{2}-f^{2}\right)$

where $p$ is the pressure of pressure cushion; $C$ is a constant; $f_{0}$ is the frequency of stress gauge in state without loading; $f$ is the frequency of stress gauge in state of loading. Different borehole pressure gauges have different $C$ and $f_{0}$. The $C$ and $f_{0}$ values of the six pressure gauges are listed in Table 5.

Table 5 Parameters of MC type bore-hole stress gauges

\begin{tabular}{cccc}
\hline $\begin{array}{c}\text { Measuring } \\
\text { point No. }\end{array}$ & $\begin{array}{c}\text { Stress } \\
\text { measurement } \\
\text { range/MPa }\end{array}$ & $C / 10^{-5}$ & $f_{0} / \mathrm{kHz}$ \\
\hline 1 & $0-20$ & 1.487 & 1.938 \\
2 & $0-20$ & 1.885 & 1.737 \\
3 & $0-20$ & 1.609 & 1.805 \\
4 & $0-20$ & 1.752 & 1.791 \\
5 & $0-20$ & 1.272 & 1.922 \\
6 & $0-20$ & 1.020 & 1.969 \\
\hline
\end{tabular}

Because MC type bore-hole pressure gauge is a flexibility measuring sensor, the elastic modulus of the measured material would influence the measuring precision of the pressure gauge. According to the following formula, the pressure of pressure cushion can be transformed into the borehole pressure.

$\sigma=\frac{10}{\alpha} p$

where $\sigma$ is the borehole pressure; $\alpha$ is the sensitivity coefficient, which can be consulted from Fig.3; and $E$ is elastic modulus of the borehole rock.

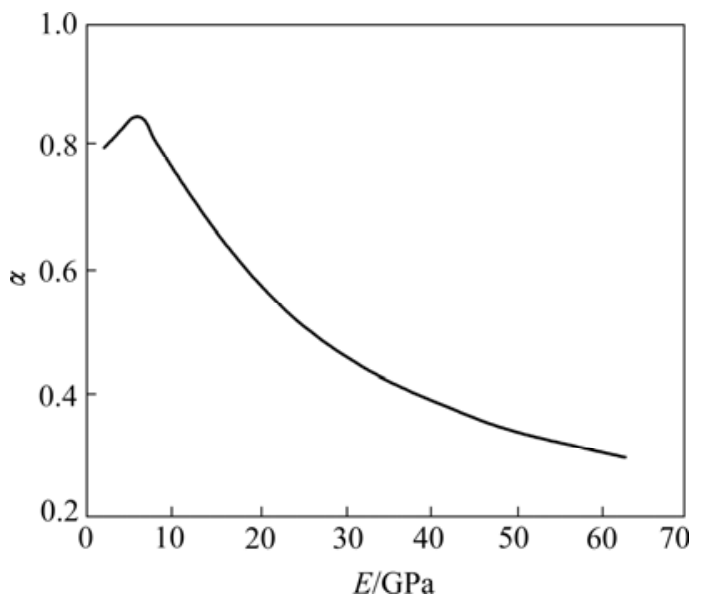

Fig.3 Relationship between of $\alpha$ and $E$ 


\subsection{Analysis of measurement results}

After installing borehole pressure gauges, the mining-induced stresses were measured every two weeks from 23 June, 2004 to 8 October, 2004. According to the measurement results, curves of stress and distance were obtained, as shown in Fig.4, where $P$ is the borehole stress, and $d$ is the distance between the measuring point and mining working face.
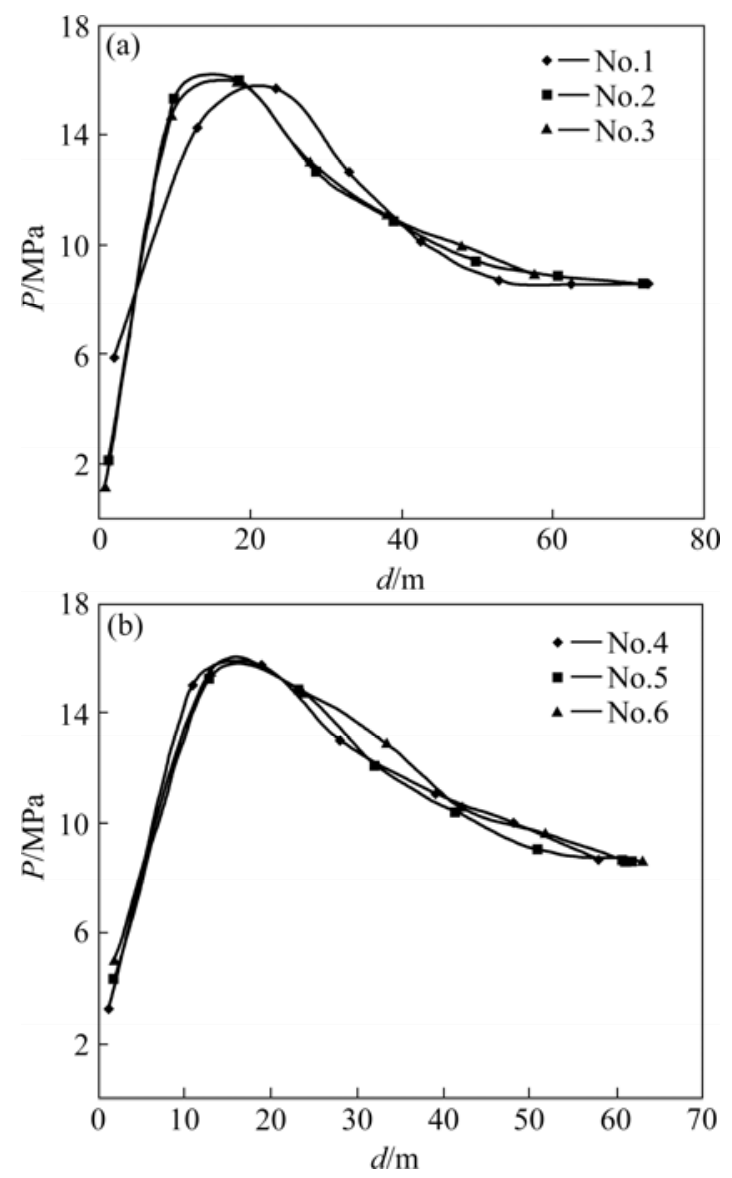

Fig.4 Stress - distance curves of measuring points No.1-3 (a) and measuring points No.4-6 (b)

Form Fig.4, the following conclusions can be drawn.

(1) The redistribution law is that, along with increasing distance between the measuring points and working face, the mining-induced stress is increased to a certain value, and then reduced to another certain value, and finally stabilized at a certain value.

(2) According to Eqn.(7), the calculated initial stress is nearly $9.46 \mathrm{MPa}$ at $-50 \mathrm{~m}$ mining level of Beiminghe Iron Mine. Before $0-3 \mathrm{~m}$ to the working face, the disturbed stress is smaller than original rock stress. Before 3-55 $\mathrm{m}$ to the working face, the mining-induced stress is larger than original rock stress. And out of the mentioned area, the disturbed stress is nearly equal to the initial stress.

(3) The maximal mining-inducing stress is $16.5^{-}$
17.5 $\mathrm{MPa}$, and it is $15-20 \mathrm{~m}$ before the mining working face. If the maximal stress is $17.5 \mathrm{MPa}$ and the original stress is $9.46 \mathrm{MPa}$, the stress concentration factor $(k)$ is 1.85 .

\section{Conclusions and suggestions}

(1) In Beiminghe Iron Mine, in order to obtain the distribution rule of in situ stress, the stress relief by overcoring technique is used to determine the in situ stress state, in which the improved hollow inclusion cell is adopted to measure the borehole strain so as to realize complete temperature compensation. The distribution law of this mine area is obtained, and the in situ stress distribution model was built. The measuring results show that the great difference between the two horizontal stresses may be the main force of the surrounding rock shear failure. The mining engineers should pay attention to the shear deformation and failure of rock mass around laneway and mining out area.

(2) From the measuring results of MC type borehole pressure gauges, the mining-induced stress can be divided into stress depressing area, stress increasing area and stress steady area. And the stress depressing area is 0-3 $\mathrm{m}$ before the working face. The stress increasing area is $3-55 \mathrm{~m}$ before the working face. The stress steady area is about $55 \mathrm{~m}$ away from the working face. The maximal of supporting stress is $16.5-17.5 \mathrm{MPa}$, which is 15-20 $\mathrm{m}$ away from the working face. The stress concentration factor $(k)$ is about 1.85 .

(3) The obtained distribution laws of in situ stress and mining-induced stress can be used to guide the mining design. For example, as to the laneways in which the ultimate strength of rock mass is less than the maximal supporting stress, in order to ensure its stability, suitable supporting steps should be taken in suitable time. As to the other laneways, no supporting was needed.

\section{References}

[1] ZHAO J, HEFNY A M, ZHOU Y X. Hydrofracturing in situ stress measurements in Singapore granite [J]. International Journal of Rock Mechanics \& Mining Sciences, 2005, 42: 577-583.

[2] SHIN K, SUGAWARA K, OKUBO S. Application of Weibull's theory to estimating in situ maximum stress $\sigma_{\mathrm{H}}$ by hydrofracturing [J]. International Journal of Rock Mechanics \& Mining Sciences, 2001, 38: 413-420.

[3] CAI M F, YU B, QIAO L, CHEN G, LI C. Experience of in situ stress measurement with hydrofracturing and overcoring techniques in Ekou mine, China [J]. International Journal of Rock Mechanics and Mining Sciences, 1997, 34(2): 299-302.

[4] CHARSLEY A D, MARTIN C D, MCCREATH D R. Sleeve-fracturing limitations for measuring in situ stress in an anisotropic stress environment [J]. International Journal of Rock Mechanics \& Mining Sciences, 2003, 40: 127-136.

[5] BECKER A. In situ stress data from the Jura Mountains - New results and interpretation [J]. Terra Nova, 1999, 11(1): 9-15. 
[6] SINGH D P, SINGH P K. An experimental approach for developing an alternative method for determining in situ stress using acoustic emission technique [J]. Indian Journal of Engineering and Materials Sciences, 1998, 5(3): 106-110.

[7] HOLCOMB D J. Observations of the Kaiser effect under multiaxial stress states - Implications for its use in determining in-situ stress [J]. Geophysical Research Letters, 1993, 20(19): 2119-2122.

[8] HUANG Song-ling, LI Lu-ming, SHI Ke-ren, WANG Xiao-feng. Magnetic field properties caused by stress concentration [J]. Journal of Central South University of Technology, 2004, 11(1): 23-26.

[9] OUYANG Zhen-hua, CAI Mei-feng, LI Chang-hong, XIE Mo-wen. Seepage effects of groundwater and its make-up water on triggering ground subsidence [J]. Journal of University of Science and Technology Beijing, 2006, 13(1): 11-15.

[10] DING De-xin, ZHANG Zhi-jun, BI Zhong-wei. A new approach to predicting mining induced surface subsidence [J]. Journal of Central South University of Technology, 2006, 13(4): 438-444.

[11] DENG Jian, BIAN Li, LI Xi-bing. Analysis of factors and countermeasures of mining subsidence in Kaiyang Phosphorus Mine [J]. Journal of Central South University of Technology, 2006, 13(6): 733-737.

[12] CAI Mei-feng, QIAO Lan, YU Bo, WANG Shuang-hong. Stress measurement with an improved hollow inclusion technique In Jinchuan Nickel Mine [J]. Journal of University of Science and Technology Beijing, 2000, 7(3): 157-160.

[13] CAI M F, QIAO L, LI C, YU J, YU B, CHEN G. Application of an improved hollow inclusion technique for in situ stress measurement in Xincheng gold mine [J]. International Journal of Rock Mechanics and Mining Science \& Geomechanics Abstracts, 1995, 32(7): 735-739.

[14] CAI M F, JI H G, WANG J A. Study of the time-space-strength relation for mining seismicity at Laohutai coal mine and its prediction [J]. International Journal of Rock Mechanics and Mining Sciences, 2005, 42: 145-151.

[15] WU Man-lu, ZHANG Chun-shan, LIAO Chun-ting, MA Yin-sheng, OU Ming-yi. The recent state of stress in the central Qinghai-Tibet Plateau according to in-situ stress measurements [J]. Chinese Journal of Geophysics, 2005, 48(2): 327-332. (in Chinese)

[16] LI F Q. In situ stress state in Mainland China [J]. Pure and Applied Geophysics, 1995, 145: 775-787.

[17] CAI M F, QIAO L, LI C, YU B, WANG S H. Results of in situ stress measurement and their application to mining design at five Chinese metal mines [J]. International Journal of Rock Mechanics and Mining Sciences, 2000, 37: 509-515.

[18] CAI Mei-feng. Measuring theory and technique of in situ stress [M]. Beijing: Science Press, 2000. (in Chinese)

[19] OUYANG Zhen-hua. Study on the coupling effect of seepage and stress on failure of mining rock mass [D]. Beijing: University of Science and Technology Beijing, 2006. (in Chinese)

[20] QIAO Lan, OUYANG Zhen-hua, LAI Xing-ping, MIAO Sheng-jun. In situ stress measuring and its result analysis in Sanshandao gold mine of China [J]. Journal of University of Science and Technology Beijing, 2004, 26(6): 569-571. (in Chinese)

(Edited by YANG You-ping) 